\title{
The Poetics of Descriptive Experience Sampling
}

\section{Holly Pester and James Wilkes}

\begin{abstract}
James Wilkes and Holly Pester, both poets, write here about their engagement with the descriptive experience sampling (DES) method, which stemmed from an interdisciplinary encounter with the psychologist Russell Hurlburt, and their experience of being trained as subjects in this technique. This chapter considers how DES can be used in unexpected ways to think through vexed questions in poetics about the relationship between experience and language, and the material ways in which experience might be captured. James and Holly consider the deployment of DES in the context of a poetry reading, which emerges as a space of multiple, distributed and distractable attention.
\end{abstract}

Keywords Poetry reading - Creative criticism - Experiment - Inner experience . Poetry

H.Pester $(\triangle)$

University of Essex, Colchester, United Kingdom

e-mail: hpester@essex.ac.uk

J. Wilkes

Durham University, Durham, United Kingdom

e-mail: wilkes_ja@yahoo.co.uk

(C) The Author(s) 2016

F. Callard et al. (eds.), The Restless Compendium, DOI 10.1007/978-3-319-45264-7_7 
Every day for three weeks we wore the earpieces in our ears and carried the gadgets in our pockets. The beep caught us out in our everyday actions (travelling, eating, cleaning, socializing, working and so on) and turned our attentions inside, into ourselves. The pause between the sound of the beep and our grabbing a pen to write the sample down was a moment of holding experience steady, ready for language.

When we were trained up in descriptive experience sampling (DES), ${ }^{i}$ we became the subjects of a psychological experiment: subjects captured or produced by a deceptively simple assemblage of people, objects and forms of inscription. But we want to propose DES as also a poetic assemblage, an assemblage that is useful for thinking about poetry. Not for what it may or may not reveal about the common experiences of people who call themselves poets, but for the thinking it prompts about the relationships between experience, writing and speech.

Do you think I'm a fantasist? No. Do you think I'm making things up? No. Do you think I'm trying to make myself look good in front of the others? No ... Well, maybe a bit; I think you probably want your experiences to be thought interesting. If that's all, then what are your reservations? I guess ... I guess you seem to be running after this thing with words, and as you run after it, it flits off; or worse, as you run after it, it starts to take on the shape of the words and really becomes them. Do you mean that Julian Opie thing? Yeah exactly - you started off using the point-light example as an approximation, you only wanted to communicate the idea of movement conjured from fragments, but as soon as you used those words the point-light image was loose, proliferating everywhere, liable to lodge in the mind, in the hand, in the notebook, ${ }^{\text {ii }}$ until it's hard to get back to what you really experienced. So you admit there is something to get back to? I'm not sure - isn't the experience elaborated in dialogue? You've used that phrase before, what do you mean by it? Elaborated? ... I mean that it comes into being somewhere in the process of speaking it. Like Heinrich von Kleist, the idea that thoughts emerge in tandem with speech? I guess so, kind of like von Kleist, though especially when the speaking happens in the presence of a zoom recorder, that silent third partner in the conversation... iii But yeah, I think it is something

\footnotetext{
${ }^{i}$ See Chap. 6.

ii See Chap. 13.

iii Cf. Chaps. 19 and 21.
} 
Kleistian, something like a rhetorical drive, a communicative urge that pulls the experience into existence. That's like R then [authors' note: infant son] - when out of nothing, out of sleep, he shakes himself into a crying rage and you're bending over the cot and all your soothing tactics just feed an anguish that seems to come from nothing, from the slightest ruffle across the water. Hair trigger feedback loop, like the onset of the beep itself, which bursts like a diver pushing up towards the surface.

At the end of each interview with Russ Hurlburt we were asked, are you committed to the description of your experience? We might ask back, what does it mean to be committed to an experience? And how can the tallying description do anything but betray experience? The question a subject has to grapple with really is: do I believe my language can communicate interior experience, or in the attempt will I slide off the path into what Denise Riley calls linguistic unease? How invested am I in the kind of significance I have given the captured experience just by framing it in speech? In the interview we elaborate on notes scribbled down at the moment we hear the beep. These spoken accounts and their transcriptions of the experience are therefore what becomes the evidence of the experience.

This act of elaboration, working out $(e x+l a b o-$ rare) through language is a work of transforming crude materials into something crafted. As the act of elaboration takes place, matter is developed into a product through the heightened application of a medium, in this case speech. A narrative is sculpted into shape, and the shape becomes data. Therefore this is not just a question of description but also of an eccentric performance of the data. Or perhaps it's true to
Elaboration: a process of working out. The interview isn't about representing a pregiven experience but about building it into being. In specialized usage, according to the dictionary, elaboration is 'the changes undergone by alimentary substances from their reception into the body to their complete assimilation'. A way of digesting experiences and transforming them into a tissue. A tissue of what? Of sound, woven between the two poles of the dialogue. Elizabeth Wilson writes about our first mind being a 'stomach-mind'. She draws on Melanie Klein to understand the primordial biological and visceral experience - the empty or full stomach of the newborn child - as also a realm of phantasy, of the psychic. If I was talking raw and cooked, about the crude materials of experience becoming language 
say that through elaboration the sample description becomes eccentric to the experience. Through elaboration the experience becomes impersonal: I write it up and then I speak it. I go to speak directly from the notes but I start to speak from a memory as well. in the interview, that would clearly be a flawed description (experience itself being shot through with the linguistic). But if we follow Wilson - and many other feminist thinkers - in understanding all objects to be alloyed, entangled or impure, then we don't need to be bound to the idea that this kind of digestion involves a definitive change of state (from phenomenal to linguistic, from apprehensible to communicable). We're less used to thinking of digestion as a communal, shared activity - but that's what I want to OR: think about now.

Ruminants' teeth move side to side, helping to grind fibrous plant matter down before it reaches their obscenely numerous stomachs. This half-remembered fact from the biology classroom prompts me to wiggle my own jaw back and forth. There's a flexibility here that the pure carnivore, with its straight meat-slicer action, lacks. That back and forth is key to the ruminatory, digestive activity that the interview performs and inscribes. Back and forth between interviewer and interviewee, but also between contradictory statements, between affirmation and self-correction, between slippages of time that are often unresolvable. This kind of communal digestion is inherently relational: it matters who you eat with because their peristaltic actions, their digestive juices as well as yours are enacting this transformation, this destruction and reconstitution. What it produces must be mutually assimilable, must be something you can both swallow, and if it isn't you'll have to chew it over until it is.

I think about the act of writing and how this makes the experience less personal. And then I wonder if the experience ever was personal. In this experiment the word 'experience' becomes an emblematic term for throwaway, randomly isolated phenomena: sensations and thoughts heard and spoken to ourselves, events imagined and fantasized. It refers to whatever is caught in the tiny frame of the beep, rather than to experience as the broader, ongoing agitations of inner self.

The material capture of this kind of experience, through the assemblage of beeper, subject, scrap of notepaper and interview, is more about what lends itself to script, to being inscribed, than it is about the self. The little moment of the beep and its description is like a process of composition. The beep isolates a feeling, removing it from the continuum of inner 
communication, and transforms it into an object to be elaborated on in various media. As with the composition of an image or phrase in photography or poetry, 'experience' is formed into a distinct object with its own material support.

DES is founded on a pragmatic supposition about language. That we might exchange words as tokens for things, that we might trade them and by doing so get closer and closer to the thing itself. That there is such a 'thing itself' uninflected by how we choose to name it or the linguistic angle we approach it from. Poetry, on the other hand, comes at this from almost the opposite direction: it's deeply invested in the ability of language to invent the world. Or, if that sounds too grandiose, the ability of language to create viable paracosms, alternate realities that might stand against the dominant one. Many artistic forms do this, but none of them uses language in quite such a thickened way as poetry does. Its linguistic surface is a treacherous one, full of unexpected temporal loops, rhythms and sounds, which rock ambivalently underfoot, sudden blind corners inserted into the long corridors of language.

When a book is in front of us we can pick our way through this field, stopping to consider particular linguistic outcroppings or roll them in our mouths, pausing to unknot something half understood, flicking back to a line we remember or misremember. But the poetry reading, that strange scene where the poet stands before us to read their work, even if they were no more than its brief and narrow conduit, often vibrating with nervousness - this scene forbids the readerly kind of back and forth, and institutes instead a different set of relations. We think the basis of these relations is a kind of suspended attention which enables a travelling with the poem, and allows you to be at some distance from it at any given time, though always with the possibility of being plunged back into it.

A beep went off when I was at a poetry reading. The experience I recorded was very precise and easily accountable: at the moment of the beep I was feeling a tightening in my throat upon hearing the poet utter the words Margaret Thatcher. The sequence of events occurred over a fraction of a second: the poet said that name, my throat tightened ('like the pain of crying', I said in my interview) and then the beep went off. The clarity of this inner experience created a strange reversal of focus. My exterior life that centred me in the room and in the world receded, and interior life, the tautening inside of my neck, quickened into a retrievable thing.

This 'sample' brought to my awareness something about the experience of listening to poetry, specifically about the material effects of words. I always intuited that having poetry read to you, and being subjected to 
the elaborated lexicons and sounds, provoked a mix of felt and thought responses. But this little event made evident the actuality of words and their violence on the body, the fact that words and phrases can incite physical reaction. .v $^{\text {on }}$

We set up a poetry reading at which the audience were beeped through speakers at four points in the proceedings. The audience members were asked to note down their inner experience at the points of the beeps that interrupted the poetry. We looked at the samples later that day and compared them, trying to see if there was a common experience of the event.

The interviews with three trained subjects showed an intense heterogeneity of experience: a close focus on particular sounds and their delivery, a generalized awareness of background hisses, florid fantasies that a poet was speaking through a hole in their shoe, and recalled voices from earlier in the day which ventriloquized words relating to the text. Of course the experiences were different; people are different. But I think it also has something to do with the way poetic language both holds and releases attention. Under its influence, the time and space of the reading can become a halo or else an atmosphere of experience, a loosely coherent object created by the common will of a group of people agreeing to gather with intention around words spoken aloud, something which allows a common travelling, variously spiked and temporally smeared. AND: around me.
At a poetry reading, a communicative force is passing between and across the group, and communication of any kind, within a single person or any group, transgresses the limits of individuation. The DES interview begs me to return the experience back to individuation, through the creation of a personalized narrative, ${ }^{\mathrm{V}}$ and more so since this narrative is treated as something over which contracted ownership is possible. However, the more I write it and speak it the more impersonal it becomes. Therefore, experience devolves into data, into property. But the beep reminds me of the post-human notion that the subject is always immersed in and immanent to a network of relations that bridge the human and non-human. While the beep sounds the myth of personal, human, individual experience, it's more truly signalling my communicative relation to objects (like the gadgets in my pocket) and viral, animal connection to the bodies

\footnotetext{
iv See Chap. 16.

${ }^{v}$ Cf. Chap. 4.
} 


\section{FurTher READING}

Braidotti, Rosi. Metamorphoses: Towards a Materialist Theory of Becoming. Cambridge, UK and Malden, Mass.: Polity Press in association with Blackwell Publishers, 2002.

Deleuze, Gilles. Dialogues. Translated by Claire Parnet. New York, N.Y.: Columbia University Press, 1987.

von Kleist, Heinrich. 'On the Gradual Production of Thoughts Whilst Speaking'. In Selected Writings, edited by David Constantine, 405-409. London: J. M. Dent, 1997.

Riley, Denise. The Words of Selves: Identification, Solidarity, Irony. Stanford, Calif. Stanford University Press, 2000.

Wilson, Elizabeth A. Gut Feminism. Durham, N.C.: Duke University Press, 2015.

Holly Pester is a poet working in experimental forms, sound and performance, and an academic at the University of Essex (in Poetry and Performance). Her work has featured at Segue (New York), dOCUMENTA 13 (Kassel), Whitechapel Gallery and the Serpentine Galleries (London).

James Wilkes is an Associate Director of Hubbub. He is a poet and writer, as well as a researcher at Durham University (Department of Geography). His interests range across contemporary and modernist poetry, audio and visual art, and their intersections with the life sciences.

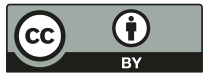

This chapter is distributed under the terms of the Creative Commons Attribution 4.0 International License (http://creativecommons.org/ licenses/by/4.0/), which permits use, duplication, adaptation, distribution and reproduction in any medium or format, as long as you give appropriate credit to the original author(s) and the source, a link is provided to the Creative Commons license and any changes made are indicated.

The images or other third party material in this chapter are included in the work's Creative Commons license, unless indicated otherwise in the credit line; if such material is not included in the work's Creative Commons license and the respective action is not permitted by statutory regulation, users will need to obtain permission from the license holder to duplicate, adapt or reproduce the material. 